\title{
Iraqi Bauxite and Porcalinite Rocks Based Refractory, Preparation and Studying Properties
}

\author{
Amel S. Merzah \\ Technical College -Baghdad /Middle Technical University \\ Email: amelmerzah@gmail.com
}

(Received 29 May 2016; accepted 15 January 2017)

https://doi.org/10.22153/kej.2017.01.004

\begin{abstract}
Locally natural occurring Iraqi rocks of Bauxite and Porcelanite (after pre calcinations at $1000^{\circ} \mathrm{C}$ for $1 \mathrm{hr}$ ) were used, with the addition of different proportions of $\mathrm{MgO}$ and $\mathrm{Al}_{2} \mathrm{O}_{3}$, to prepare refractory materials. The effects of these additives on the physical and thermal properties of the prepared refractories were investigated.

Many batches of Bauxite/MgO, Bauxite/ $\mathrm{Al}_{2} \mathrm{O}_{3}$, Bauxite/ $\mathrm{MgO} / \mathrm{Al}_{2} \mathrm{O}_{3}$, and Porcelanite $/ \mathrm{MgO} / \mathrm{Al}_{2} \mathrm{O}_{3}$ were prepared. The mixture is milled and classified into different size fractions; fine (less than $45 \mu \mathrm{m}) 40 \%$, middle $(45-75 \mu \mathrm{m}) 40 \%$, and coarse $(75-106 \mu \mathrm{m}) 20 \%$.

$\mathrm{X}$-ray diffraction technique was used to identify the structure of Bauxite and Porcelanite rocks. The samples were formed by semi dry pressing with the addition of few drops of water as a binder. These samples were sintered at $1100^{\circ} \mathrm{C}$ for $2 \mathrm{hrs}$. Physical properties (linear shrinkage, density and porosity), and the thermal properties (thermal conductivity, diffusivity and specific heat) were measured for all the prepared samples.

The results show the increasing of density is susceptible to the thermal properties, and also the addition of $\mathrm{Al}_{2} \mathrm{O}_{3}$ and $\mathrm{MgO}$ to the natural rocks have a limited effect, and the values of the parameters above for the natural rocks, were in the levels to be used as a refractory material for lining a metal fusion furnaces and other applications.
\end{abstract}

Keywords: Bauxite, Refractory brick, Porcelanite Stone, Physical properties, Thermal properties.

\section{Introduction}

A refractory is a material that retains its shape and chemical identity during exhibition to high temperatures and used in such applications that require extreme resistance to heat. Almost all raw materials used by refractory manufacturers occur naturally. But they are prepared or processed in several ways to lower the fluxes, unwanted oxides as much as possible. In general, refractory materials may contain the following oxides: silicon dioxide, aluminum oxide, magnesium oxide, calcium oxide, chromium oxide, and zirconium dioxide [1].

Firebricks, like any other ceramic products are prepared through three main stages: raw materials preparation (mixing according to definite proportion using milling process and then sieving to a definite particle size), pressing to compacts and densification through the sintering process. The main constituents of firebricks usually contain alumina $\left(\mathrm{Al}_{2} \mathrm{O}_{3}\right)$ and silica $\left(\mathrm{SiO}_{2}\right)$. These systems are actually based on kaolinitic clays, which generally produce a substantial shrinkage when sintered [3].

Fireclay refractories, also known as chamotte bricks, belong to the aluminosilicate group with alumina content between 25-45 wt $\%$. The foreboding raw material for making fireclay refractories was kaolin. Kaolin mainly composed of alumina, which is used in the manufacturing of fireclay refractories among other industrial minerals [4]. The higher the alumina contents of kaolin, the higher the refractoriness. Raw materials are thus classified to be of high 
refractory value as the amount of alumina in them increases [5].

Firebrick or refractory was the major consumables to industries wherever heat is used, and abrasion and acid resistance is required including the following industries: iron and steel, copper, gold, platinum, Ferro-alloys, aluminum, cement, lime, glass, ceramics, foundries, and gas plants, chemical plants, petroleum plants, and power stations [6]. The iron and steel industry, considered as the largest consumer, estimated between $50-80 \%$ of the refractories produced worldwide. Refractories used for the following purposes [7].

Lining of plants for thermal processes, such as melting, firing, heat treatment furnaces, and transport vessels.

Fireclay refractory was charecterized by low thermal expansion coefficient, low thermal conductivity, low specific gravity, low specific heat, low strength at high temperature, and less slag penetration [8].

In the present work naturally, locally occurring rocks, Bauxite and Porcelanites were used to prepare a refractory batch to be used in the above applications.

Bauxite is a rock formed from a laterite soil that severely leached from Silica Alumina and other soluble materials.

Bauxite, known as a soft white to gray to reddish brown rock with a pisolitic structure, earthy luster and a low specific gravity (SG: 2.02.5) [15].

Bauxite is a naturally occurring (in Al- Anbar and western desert in Iraq), heterogeneous material composed primarily of one or more aluminum hydroxide minerals, plus various mixtures of silica, iron oxide, titania, aluminosilicate, and other impurities in minor or trace amounts[12].

Porcelanites are siliceous rocks, found in Iraq, are from an industrial bed of $(0.5$ to $1.3 \mathrm{~m})$ thickness in the Safra, and Trafawi site of the Jeed formation in Al-Rutba region, western of Iraq, it composed of opal- CT (crystallite- tridymite crystal stratification) and are derived from biogenic amorphous opalline silica, associated with shale.

Pocelanites; these are siliceous rocks, they are part the phosphorene in the western (Digme and Akashat formations respectively)[13].

The present work aims to study the physical and thermal properties of refractory prepared from Bauxite/Alumina/Magnesia and Porcelanite/ Alumina/ Magnesia, and decide the effect of addition, and their effect on the physical and thermal properties of refractory.

\section{Experimental Part}

Local raw materials, bauxite with chemical analysis shown in table (1), porcelanite rocks with a mineral analysis ( from state company of geological survey and mining, Baghdad, Iraq), shown in Table (2), alumina and magnesia were used as starting materials. The natural rocks were pre calcined at $1000^{\circ} \mathrm{C}$ for $1 \mathrm{hr}$. The same technology was used to prepare a refractory sample with varying proportions as given in table (3) and table (4).

Table 1,

Anbar and Western Desert Bauxite chemical composition.

\begin{tabular}{lllllll}
\hline Compound & $\mathrm{MgO}$ & $\mathrm{CaO}$ & $\mathrm{TiO}_{2}$ & $\mathrm{Fe}_{2} \mathrm{O}_{3}$ & $\mathrm{SiO}_{2}$ & $\mathrm{Al}_{2} \mathrm{O}_{3}$ \\
$\begin{array}{l}\text { Maximum } \\
\text { wt\% }\end{array}$ & 1.1 & 1.2 & 1.8 & 1.3 & 20 & 60 \\
\hline
\end{tabular}

Table 2,

Mineral analysis of as received porcelainte stone.

\begin{tabular}{ll}
\hline Compound & Wt.\% \\
\hline Opal- CT & 64.28 \\
Quartz & 10.42 \\
Clay & 7.72 \\
Dolomite & 7.12 \\
Calcite & 6.30 \\
Apatite & 1.83 \\
Halite & 0.63 \\
Gypsum & 0.61 \\
\hline
\end{tabular}

Table 3,

Mixing ratios in weight percentages of starting materials to prepare Bauxite based refractory.

\begin{tabular}{llll}
\hline $\begin{array}{l}\text { Batch } \\
\text { number }\end{array}$ & $\begin{array}{l}\text { Bauxite } \\
\text { wt \% }\end{array}$ & $\begin{array}{l}\text { Alumina } \\
\text { wt } \%\end{array}$ & $\begin{array}{l}\text { Magnesia } \\
\text { wt\% }\end{array}$ \\
\hline 1 & 60 & 40 & \\
2 & 60 & & 40 \\
3 & 60 & 20 & 20 \\
4 & 100 & & \\
\hline
\end{tabular}

The mixture is milled and classified into different size fractions; fine (less than $45 \mu \mathrm{m}$ ) $40 \%$, middle $(45-75 \mu \mathrm{m}) 40 \%$, and coarse (75$106 \mu \mathrm{m}) 20 \%$. 
Table 4,

Mixing ratios in weight percentages of starting materials to prepare Porcelanite based refractory.

\begin{tabular}{llll}
\hline $\begin{array}{l}\text { Batch } \\
\text { number }\end{array}$ & $\begin{array}{l}\text { Porcelanite } \\
\text { wt } \%\end{array}$ & $\begin{array}{l}\text { Alumina } \\
\text { wt\% }\end{array}$ & $\begin{array}{l}\text { Magnesia } \\
\text { wt\% }\end{array}$ \\
\hline 1 & 100 & & \\
2 & 60 & 20 & 20 \\
3 & 50 & 10 & 40 \\
4 & 50 & 40 & 10 \\
5 & 50 & 25 & 25 \\
6 & 25 & 50 & 25 \\
7 & 25 & 25 & 50 \\
8 & 40 & 40 & 20 \\
\hline
\end{tabular}

The mixing process was achieved using a porcelain ball mill as shown in figure (1); sieve analyzer was used to classify the powder particle sizes as shown in figure (2).

The formed samples were sintered in an electrical furnace at $1100^{\circ} \mathrm{C}$ for $2 \mathrm{hrs}$.

$\mathrm{X}$-Ray diffraction technique was used to identify the local rocks composition and contents.

Physical and thermal properties were measured for all samples, such as density, porosity, shrinkage, thermal conductivity, thermal diffusivity and specific heat.

The thermal properties such as thermal conductivity, thermal diffusivity, and specific heat, were measured for each sample by "Hot Disc" system in the Material Engineering Department in the university of technology as shown in fig (3,a and b). The results were supplied from computer linked with the device.

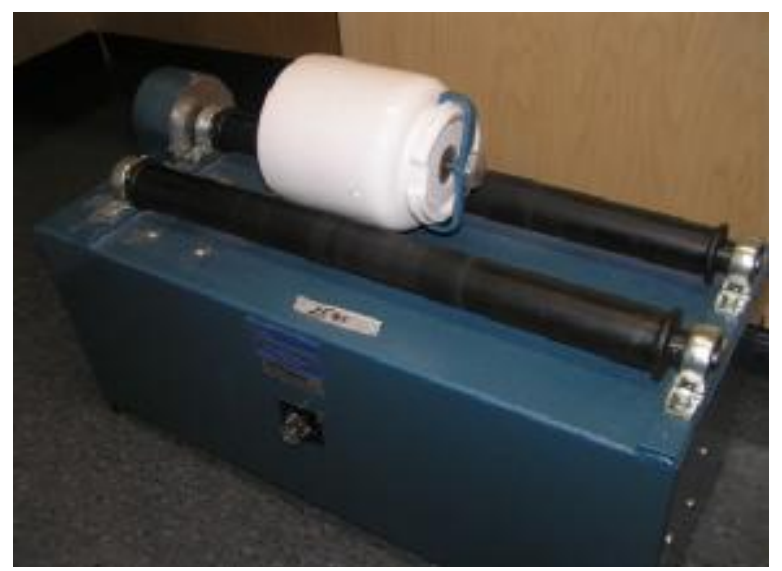

Fig. 1. A porcelain ball mill used for milling and mixing.

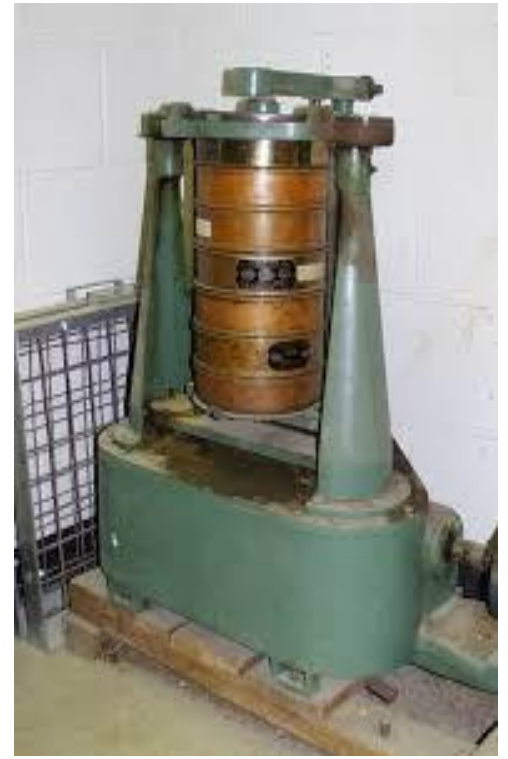

Fig. 2. Sieve analysis system.

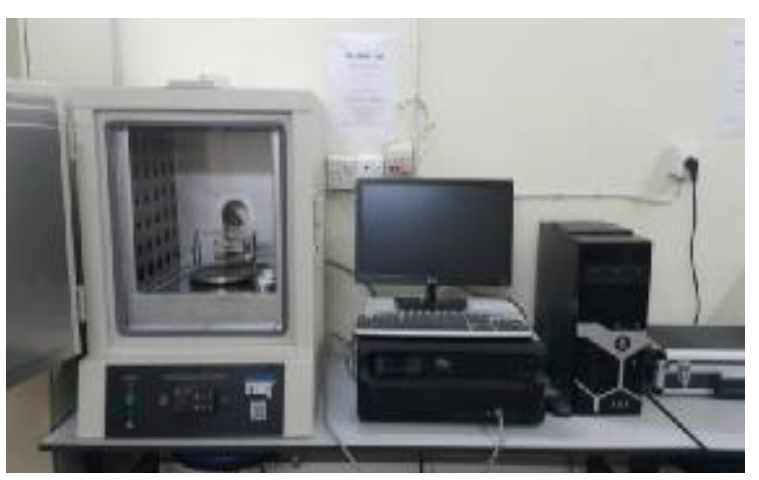

(a)

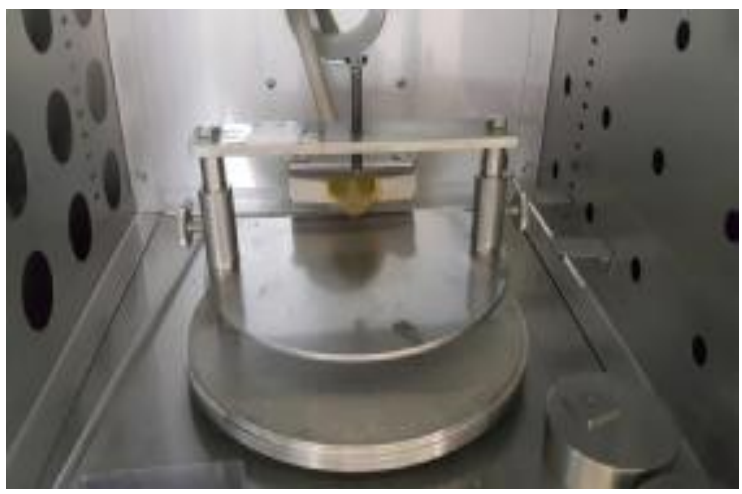

(b)

Fig. 3. (a)Thermal properties apparatus, (b) Holder of the sample.

Physical property requirements for shaped and unshaped refractories are different. For shaped refractories, the main requirements are their density and porosity and dimensional tolerance, which achieved in the present work. 
Apparent density: The apparent density is generally considered in conjunction with apparent porosity.

$\rho_{\mathrm{a}}=\frac{\mathrm{Wd}}{\mathrm{Ws}-\mathrm{Wi}} \times \rho_{\mathrm{w}}$

Where:

$\rho_{\mathrm{a}}$ is the apparent density for the prepared samples in $\mathrm{gm} / \mathrm{cm}^{3}$

Wd: Weight of dried sample (gm)

Wi: Weight of immersed sample (gm)

Ws: Weight of wet ( open pors filled with water sample (gm)

$\rho_{\mathrm{w}}$ : Density of water in $\mathrm{gm} / \mathrm{cm}^{3}$

Shrinkage: - shrinkage means that mixture could absorb much water, which in turn indicates fine mixture particles.

\section{Linear Shrinkage $=\frac{H 1-H 2}{H 1} \times 100 \%$}

Where: - $\mathrm{H}_{1}$ : - height of the sample before sintering in $\mathrm{cm}$

$\mathrm{H}_{2}$ : - height of the sample after sintering in $\mathrm{cm}$.
Apparent Porosity: -Porosity is a measure of the effective open pore space in the refractory and is expressed as the average percentage of open pore space in the overall refractory volume.

Porosity $\%=\frac{W s-W d}{W s-w i} \times 100 \%$

Where: -

Wd: $\quad$ Weight of dried sample (gm)

Wi: Weight of immersed sample (gm)

Ws: Weight of wet ( open pors filled with water sample (gm)

\section{Results and Discussion}

The chemical composition of Bauxite as received was given in table (1), from which it is appeared that the main compounds are alumina and silica with small weight ratios of other oxides. The X-Ray data for Iraqi Bauxite used in the present work was shown in figure (4).

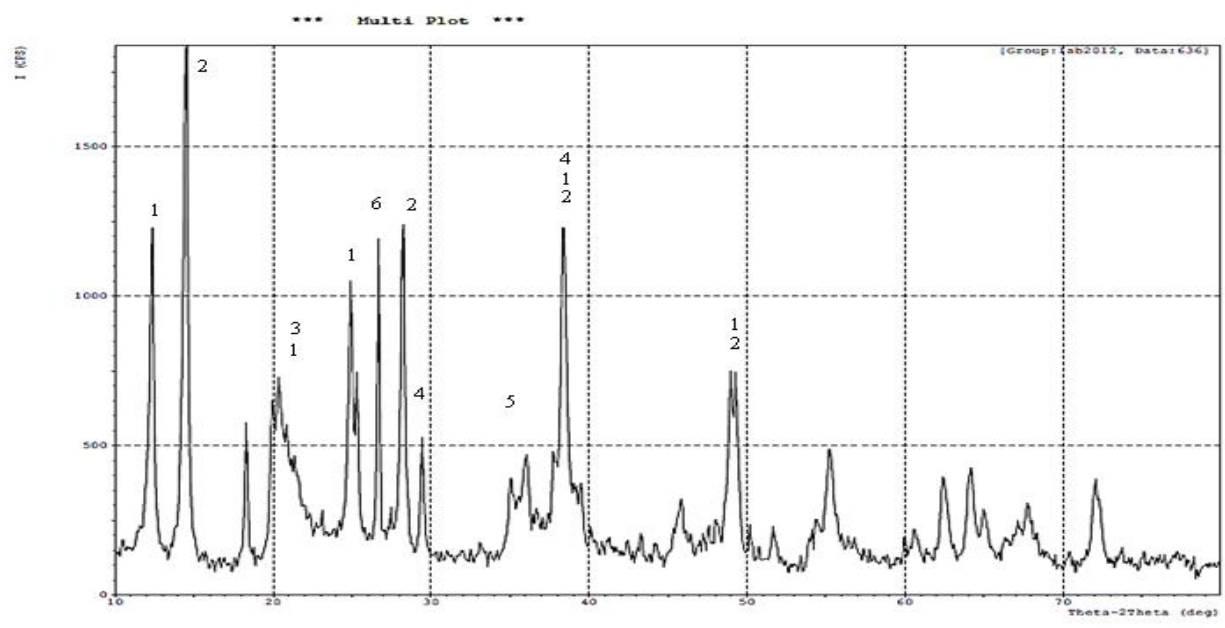

1. Kaolinite 2 .Bohmite 3.Gibbsite 4.Anatase 5.Quartz 6.Calcite

Fig .4. X-ray diffraction pattern for Iraqi Bauxite as reserved from the Geologized surveying company.

The figure shows that the bauxite rock consist of Kaolinite, Anatase, Bohmite Quartz, Gibbsite, and Calcite. After cacination the alumina and silica form the Mullite.

Table (2) shows the chemical analysis of the porcelanite stone as received from the source, the silica minerals which are mainly disordered $\alpha$ cristobalite opal-CT and quartz are the main compounds. Chemical analysis of opal-CT shows that they contain an appreciable amount of alkaline and alkaline earth elements (Millot, 1970)[9], which means that if foreign cations are available in appreciable amount, opal-CT can precipitate. The experimental results by Kastner et al. (1977)[10] suggest that magnesium hydroxides are the most important components responsible for the increased rate of amorphous silica (opalA) digenesis. This is analogous to aragonite, an unstable form of calcite, which precipitates in the presence of magnesium ions (Health and Moberly, 1971) [11]. In carbonates of over 80 per cent $\mathrm{CaC03}$, as in Figure 4, both the scarcity of aluminum and metallic cations favor precipitation of opal-CT only, The porcelanite after calcinations at $1000^{\circ} \mathrm{C}$ for $1 \mathrm{hr}, \mathrm{X}$-ray diffraction data was given in figure (5). 

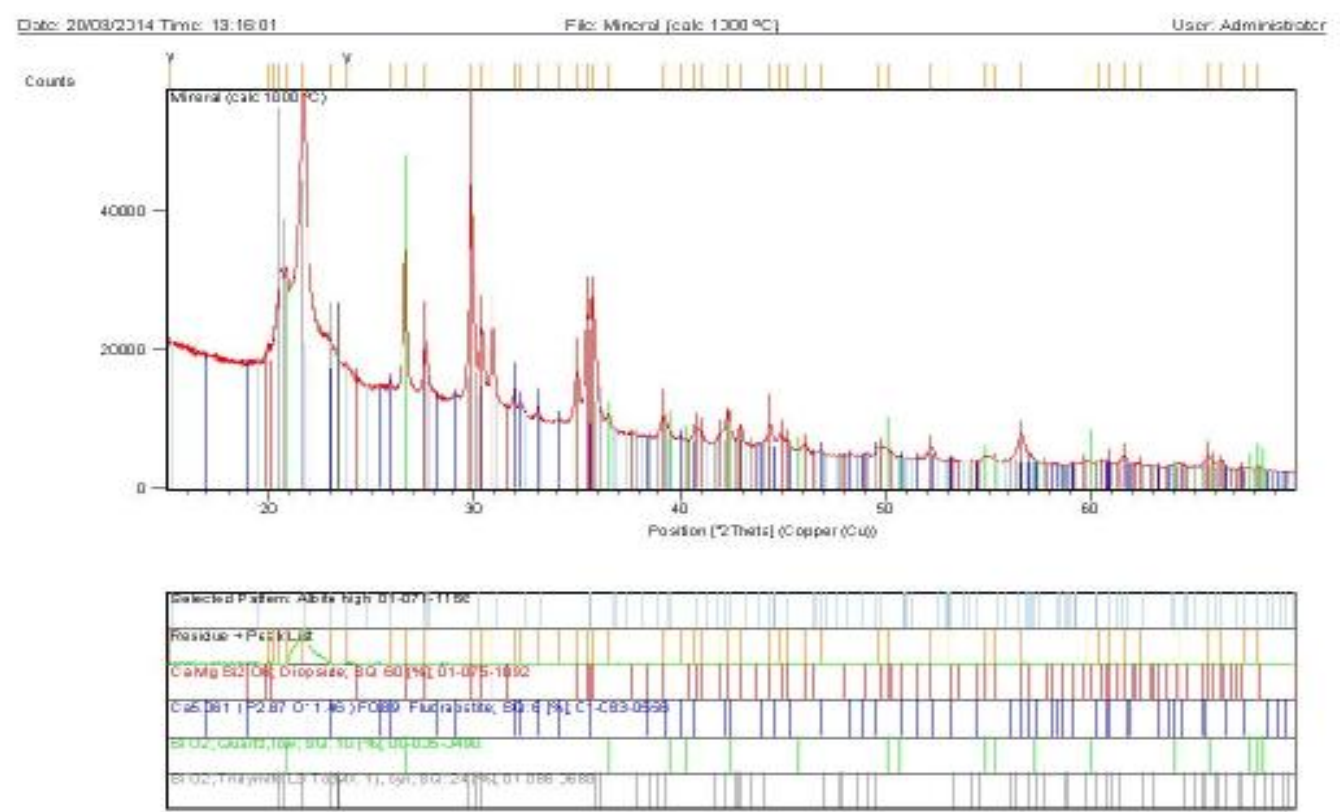

Page 1 of 1

Fig. 5. X-ray diffraction data of Porcelanite mineral, (examination was conducted in laboratories of Sheffield Hallam University using a theta to theta diffractometer (Philips)).

It was appeared from figure (5) that there are three strong peaks which indicates appearance of silica, at angle 2 theta (21.6909 and 20.7108) silica appeared in (tridymite form), and at (30.9435) silica appears in quartz form and final small peak for ( $\mathrm{CaCO} 3)$.The later compounds appeared because of the calcinations at $1000^{\circ} \mathrm{C}$, the contents of the rock which is seen in table (2), are reacted with each other to form the compounds appeared in fig.(5).

Table (3) shows the mixing ratios in weight percentages of starting materials to prepare Bauxite based refractory, using the largest percentages of Bauxite in order to get the glassy phase or liquid phase and increase the shrinkage and density after sintering the samples, these results were appeared from table (5), which shows the physical and thermal properties for the bauxite based prepared refractory, the denser compound is the alumina as seem in sample number 1 which has the greater density $2.16 \mathrm{gm} / \mathrm{cm}^{3}$, while sample number 3 has the lowest. Reduction of porosity in the sample number 4 which is mainly Bauxite is due to the presence of impurities have low melting points, increases the glassy phase in the prepared refractory. Increasing $\mathrm{MgO}$ give rise to a reduction in the viscosity of the liquid phase formed, so the pores filled and shrinkage increased to $8 \%$. Also the physical and thermal properties depend on the size graduation.

Table 5,

The physical and thermal properties for the bauxite based prepared refractory.

\begin{tabular}{lllllll}
\hline $\begin{array}{l}\text { Sample } \\
\text { No. }\end{array}$ & L.Sh. & $\begin{array}{l}\text { \% Apparent } \\
\text { Porosity }\end{array}$ & $\begin{array}{l}\text { Sintered Density } \\
\mathbf{g m} / \mathbf{c m}^{\mathbf{3}}\end{array}$ & $\begin{array}{l}\text { Thermal Cond } \\
\text { w/m.K }\end{array}$ & $\begin{array}{l}\text { Diffusivity } \\
\text { Mm2/sec }\end{array}$ & $\begin{array}{l}\text { Specific Heat } \\
\text { MJ/m3.K }\end{array}$ \\
\hline 1 & & 27.7 & 2.16 & 0.66 & 0.35 & $1.09 * 10^{3}$ \\
2 & 0.0270 & 1.77 & 1.55 & 0.34 & $2.09 * 10^{3}$ \\
3 & 0.0830 & 21.2 & 1.79 & 0.85 & 0.43 & $1.11 * 10^{3}$ \\
4 & 0.0026 & 9.6 & 1.73 & 0.38 & 0.24 & $0.91 * 10^{3}$ \\
\hline
\end{tabular}

Porosity can be controlled by controlling the size distribution of the particles. Higher the porosity, lower will be the strength of the brick. Bricks with lower porosity will have greater resistance to slag attack and more sensitiveness to fluctuations in temperature. Their thermal conductivity will be more.

It can be seen from table (5) that the apparent porosity is ranged between (9.6-27.7) \%. The relationships between apparent porosity and the 
percentages of Alumina and Magnesia percentage, the higher the Alumina the higher the density, this is due to the strengthening by alumina, the high density is balanced with high porosity, while the sample of only Bauxite shows the lower. Chemical reactions may take place between the components, $\mathrm{MgO}, \mathrm{Al}_{2} \mathrm{O}_{3}, \mathrm{Fe}_{2} \mathrm{O}_{3}$, and $\mathrm{CaO}$. Low fusion temperature compounds were formed, which flow easily into the pores and increase the density of refractory. Also the surface tension of liquid phase cause a compacting and reducing the dimensions of the refractory.

The table (6) and figures (6, 7 and 8), shows the physical and thermal properties of the prepared porcelanite based refractory.

Table (6)

The physical and thermal properties of the prepared porcalinite based refractories.

\begin{tabular}{lllllll}
\hline $\begin{array}{l}\text { Sample } \\
\text { No. }\end{array}$ & L.Sh. & $\begin{array}{l}\text { Sintered } \\
\text { Density } \\
\text { gm/cm3 }\end{array}$ & $\begin{array}{l}\text { Apparent } \\
\text { porosity } \\
\text { \% }\end{array}$ & $\begin{array}{l}\text { Thermal } \\
\text { Cond } \\
\text { w/m.K }\end{array}$ & $\begin{array}{l}\text { Diffusivity } \\
\text { Mm2/sec }\end{array}$ & $\begin{array}{l}\text { Specific Heat } \\
\text { MJ/m } \mathbf{3} \cdot \mathbf{K}\end{array}$ \\
\hline 1 & & 1.36 & 10.6 & 0.42 & 0.19 & 2.27 \\
2 & 0.031 & 1.2 & 0.34 & 0.21 & 2.06 \\
3 & 0.025 & 1.44 & 10.1 & 0.36 & 0.29 & 1.26 \\
4 & 0.030 & 1.44 & 10.8 & 0.27 & 0.14 & 1.93 \\
5 & 0.030 & 1.39 & 11.1 & 0.31 & 0.16 & 1.90 \\
6 & 0.024 & 1.42 & 10.9 & 0.25 & 0.21 & 1.95 \\
7 & 0.029 & 1.40 & 10.5 & 0.33 & 0.17 & 1.36 \\
8 & 0.051 & 1.40 & 11.8 & 0.28 & 0.21 & \\
\hline
\end{tabular}

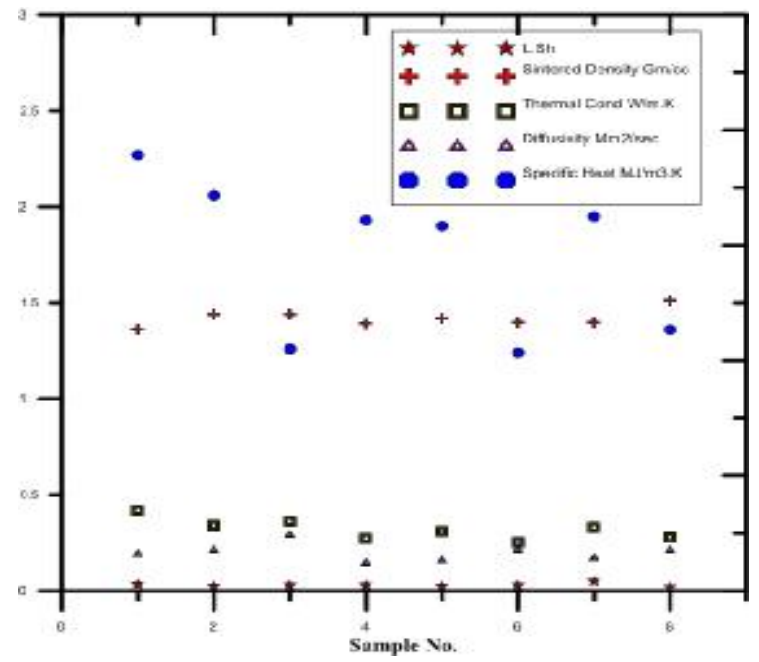

Fig. 6. The linear shrinkage, sintered density, thermal conductivity, and the diffusivity for different batches of the Porcelanite prepared refractory (as given in table 4)

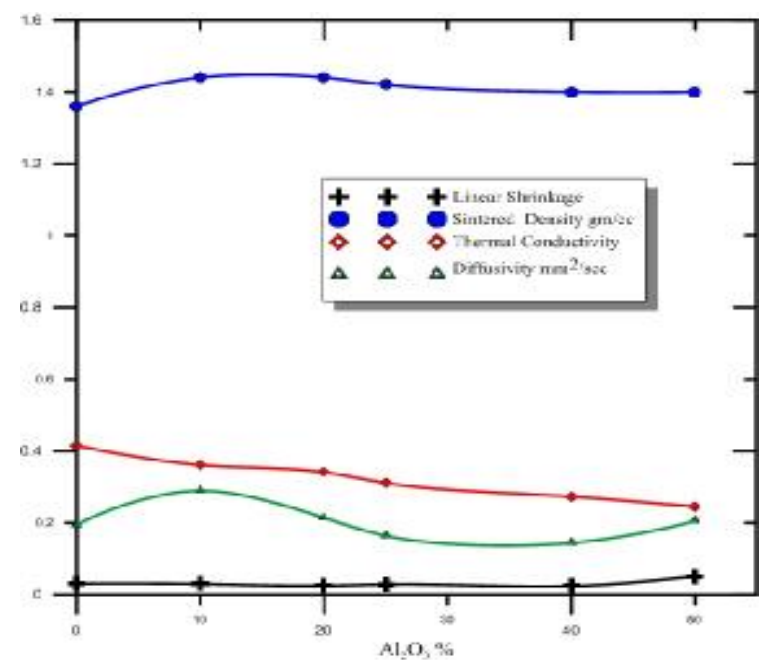

Fig. 7. The linear shrinkage, sintered density, thermal conductivity, and the diffusivity for the Porcelanite prepared refractory as a function of $\mathrm{Al}_{2} \mathrm{O}_{3}$ percentages. 


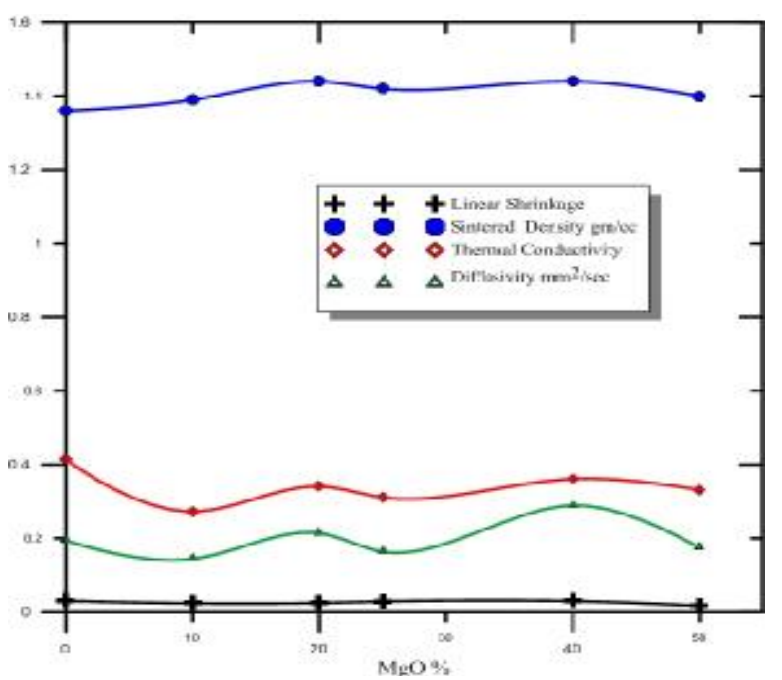

Fig. 8. The linear shrinkage, sintered density, thermal conductivity, and the diffusivity for the Porcelanite prepared refractory as a function of MgO percentages.

There is flocculating in the properties appeared in figures, in general all the prepared samples are suitable as refractory. High alumina ratio increase the density of the product.

The impurities fluxes materials $\mathrm{k}_{2} \mathrm{O}, \mathrm{Na}_{2} \mathrm{O}$, $\mathrm{CaO}$ and $\mathrm{MgO}$ ) that extent within the material structure reacts to form the large amount of fusible materials, which have small densities compared with the alumina and magnesia.

\section{Conclusions}

Fireclay refractory's, like other ceramic products are processed through three main stages: raw materials preparation, consolidation to compacts and densification by sintering. The main constituents of fireclay refractory are alumina $\left(\mathrm{Al}_{2} \mathrm{O}_{3}\right)$ and silica $\left(\mathrm{SiO}_{2}\right)$. These systems are normally based on kaolinite clays which generally present substantial shrinkage when fired [12]. In the present work the bauxite and porcelanite rocks were used instead, because of their abundance in Iraqi earth crust and it contains large percentages of kaolin and silica respectively. Figures above shows the physical and thermal properties of the prepared refractory according to the formulas given in table $(3,4)$, the stability in the values of these properties, especially the lowest values of shrinkage, suggest using the batches prepared as a good refractory material $[13,14]$. This is the first time porcelanite used as a main constituent for refractory applications, also the bauxite is expected to be good refractory material.

The bauxite and the porcelanite are a suitable choice for refractories, because of the low costs and availability, suggested as a future material for fire bricks manufacturing.

The effect of $\mathrm{MgO}$ and $\mathrm{Al}_{2} \mathrm{O}_{3}$ addition have a limited effect on the thermal and physical properties of the bauxite and porcalinite, which ensure using the bauxite or porcalinite as a refractory material.

\section{References}

[1] Y. Chen, M.M. Abraham, M. T.Robinson, J.B. Mitchell and R.A. Van Konynenburg, Proc. Intern. Conf. on Radiation Effects and Tritium Tech. Fusion Reactors, Gatlinburg, TN. (1975), USERDA CONF 750989 Vol. II. p. 492.

[2]-Chaouki Sadik1, Abderrahman Albizane1, IzEddine El Amrani, "Production of porous firebrick from mixtures of clay and recycled refractory waste with expanded perlite addition",J. Mater. Environ. Sci. 4 (6) (2013) 981-986.

[3] John Baptist Kirabira," Characterisation of Ugandan raw-minerals for firebricks -before and after sintering", Royal Institute of Technology Department of Materials Science and Engineering Division of Mechanical Metallurgy Stockholm 2003.

[4]D. Salmon, S. Baxendale, G. Groboth, B. Hay, U. Hammerschmidt, R. Brandt, S. Sinnema, D. Baillis, R. Schreiner, J. Blumm, E. Dossou, 'The certification of thermal conductivity and diffusivity properties of Pyroceram 9606 as a reference material up to $1000{ }^{\circ} \mathrm{C}$, Final report Project HTCRM, contract $\mathrm{n}^{\circ}$ SMT4-CT982211, 2003.

[5] G. Viruthagiri, Sri Nithya, Nareshanada and N. Shanumugan, "Analysis of insulating fire bricks from mixtures of clays with Sawdust addition", ISSN-2249-555x, Vol.3, Issue 6, June 2013.

[6] John Baptist Kirabira," Properties of Ugandan minerals and fireclay refractories", Doctoral thesis, Stockholm, Sweden 2005.

[7] Chesters, J.H. (1983). "Refractories: Production and properties". Institute of materials, London, UK.

[8] Fatai Olufemi Aramide, "Production and Characterization of Porous Insulating Fired Bricks from Ifon Clay with Varied Sawdust Admixture", Journal of Minerals and Materials 
Characterization and Engineering, 2012, 11, 970-975.

[9] Millot, G., 1970. Geology of Clay: New York (Springer-Verlag). Stein, C.L. and Kirkpatrick, R.J., 1976. Experimental porcelanate recrystallization kinetics: A nucleation and growth model, J. Sediment. Petrol, v. 46, p. 430-435.

[10] Kastner, M., Keene, J.B., and Gieskes, J.M., 1977. Diagenesis of siliceous oozes- 1 . Chemical controls on the rate of opal-CT transformation- an experimental study, Geochim. Cosmochim. Acta, v. 41, p. 10411059.

[11] Heath, G.R. and Moberly, R., 1971. Chert from the western Pacific, Leg 7, Deep Sea Drilling Project. In Winterer, E.L., et

[12] Al-Zubaidi, A.A.,(2010):Origin of Silica Minerals in the Geodes of the Iraqi Western Deset. Fifth International Conference on the Tethys. Cairo University, Cairo.

[13] Khaldoun S. Al-Bassam," Geology of Iraqi Western Desert ", Iraqi Bull. Geol. Min. Special Issue, 2007: p 145-168.
[14] O.S. Olokode*; P.O. Aiyedun; D.M. Raheem; F.T. Owoeye and B.U. Anyanwu, "Production and characterization of clay cow dung insulating fire - bricks", (ISSN: 2315-5124) Vol. 1(7) pp. 162-167, October, 2012.

[15] Stephen Stackhouse, Lars Stixrude and Bijaya B. Karki, "Thermal Conductivity of Periclase $(\mathrm{MgO})$ from First Principles", PRL 104, 208501 (2010) P H Y S I C A L R E V I E W L E T T E R S, week ending 21 MAY 2010.

[16] Shigetaka Wada, Bongkoch Piempermpoon, Pao Na Nakorn, Thanakorn Wasanapiarnpong and Supatra Jinawath, "Thermal Conductivity of A12O3 Ceramics: The Inconsistency between Measured Value and Calculated Value" J. Sci. Res. Chula. Univ., Vol. 30, No.1 (2005). 


\section{الخصائص الفيزيائية والحرارية لحراريات مصنعة من صخور البوكسايت والبورسلينات \\ العراقية}

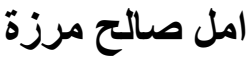

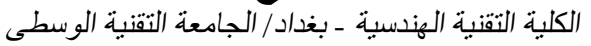

البريد الالكتروني: amelmerzah@gmail.com

\section{الخلاصة}

الصخور المحلية الموجودة طبيعيا في العراق (البوكسايت والبورسلينات) والمحروقة اولياً بدرجة حرارة ـ . . الدرجة مئوية ولمدة ساعة واحدة، تم

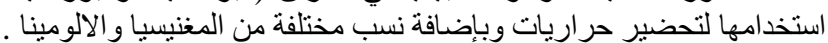

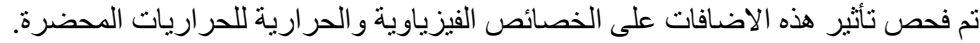

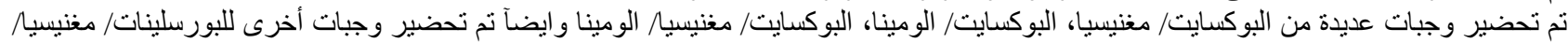

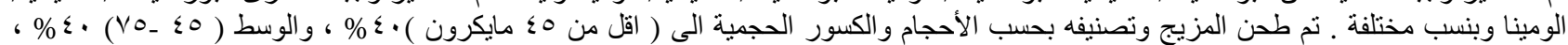

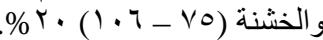

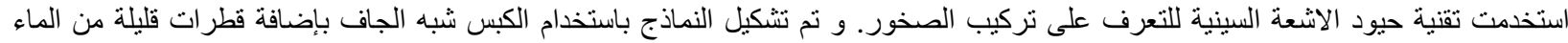

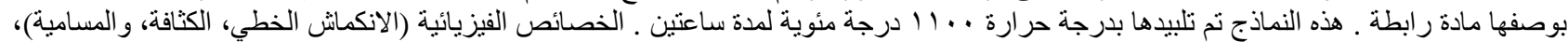

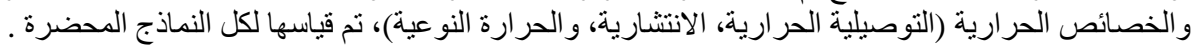

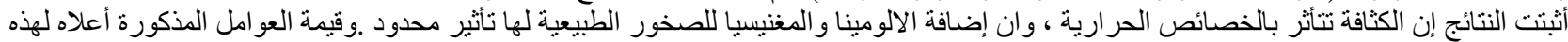

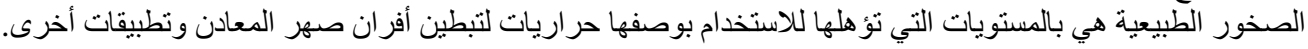

